\title{
Psychological Challenges Affecting HIV and AIDS Counselors, Possible Models and Solutions: A Zimbabwean Perspective
}

\author{
Jane Mbetu-Nzvenga $^{1}$, Ephias Gudyanga ${ }^{2}$ \& Anna Gudyanga ${ }^{2}$ \\ ${ }^{1}$ Gweru Polytechnical College, Department of Education, Gweru, Zimbabwe \\ ${ }^{2}$ Midlands State University, Faculty of Education, Gweru, Zimbabwe \\ Correspondence: Ephias Gudyanga, Midlands State University, Faculty of Education, P. Bag 9055, Gweru, \\ Zimbabwe. Tel: 26-37-7324-3468. E-mail: gudyangae@msu.ac.zw
}

\author{
Received: June 25, 2013 Accepted: September 24, 2013 Online Published: November 29, 2013 \\ doi:10.5539/ass.v9n17p10 \\ URL: http://dx.doi.org/10.5539/ass.v9n17p10
}

\begin{abstract}
This paper sought to find out the psychological challenges affecting counselors during HIV and AIDS counseling sessions. The background information focused on what HIV and AIDS counseling is and how it affects counselors and individuals who are HIV positive. Qualitative and quantitative research designs were employed. We randomly sampled ten participants out of a population of thirty (33.3\%), eight females and two male nurses/counselors and five female clients who were HIV positive and were living positively. These five had gone through HIV and AIDS counseling. The main data collecting instruments were questionnaires, unstructured interviews and focus grouping. The five clients constituted a focus group. Responses from focus group discussions were presented in a thematic way. It was found out that counselors work under pressure. They face emotional burnout and they are stressed up. They need psychological support from the authorities and colleagues. It was concluded that the Ministry of Health is encouraged to facilitate more workshops and send health workers for further training so as to make them keep abreast with modern trends in HIV counseling and to increase counseling skills as well as to make them feel more competent in their profession.
\end{abstract}

Keywords: counselor, counseling, therapy, client, HIV/AIDS

\section{Introduction}

This paper deals with the psychological challenges affecting counselors during HIV and AIDS counseling session.

Counseling is a face to face communication, in which a counselor helps a client to identify, clarify and resolve a problem in order to make an informed decision (Hayes, 1993). HIV and AIDS counseling involves confidential dialogue between a client and a health worker aimed at enabling a person to evaluate personal risk of HIV transmission and make decision related to HIV and AIDS (Nkwi \& Bernard, 2012). Counseling is important in promoting behavior change and in enabling the client or couple to cope with stress and to take personal informed decision in the context of HIV and AIDS. The stress of knowing the positive status in the absence of a cure may often be regarded as a death sentence, together with the stigma (Mottia, 2012) that accompanies the illness may trigger an acute stress, depression and or anxiety. Mental disorders and incidences of suicide may result as a complication of HIV and AIDS infection. Therefore HIV and AIDS counseling is a very sensitive issue where the counselor needs to be highly skilful and avoid the embarrassment and cause psychological trauma to the client (Gudyanga \& Gudyanga, 2012). Counseling of stressed or depressed clients comes with a lot of challenges.

All those caring for people with HIV and AIDS, family, friends and professional care givers may need extra support themselves (Jackson, 1992) to cope with the emotional trauma of AIDS. Health workers and counselors are commonly expected to cope professionally with their emotions. Counselors are expected to hide their emotions, however upset, angry or frustrated they may feel. The counselor's work may be stressful because they repeatedly face the ill-health, the suffering and dying people. HIV and AIDS counseling may also be stressful because HIV is a problem that may affect any one of us even the counselor, his/her friends, family members. Counselors may worry that they are personally at risk of HIV and AIDS from sex and or from their work. Some counselors are aware that they have HIV and AIDS (they are affected) and yet must continue working with HIV 
and AIDS infected patients, providing support for others when they (counselors) need it themselves. Counselors may become over-involved with patients, eventually finding that they (counselors) could not cope and leave the job. Therefore this research seeks to find the psychological challenges affecting counselors during HIV and AIDS counseling session at Manhumba Rural Hospital.

The hospital caters for patients from Manhumba Township, the surrounding farms. The target age group of clients being counseled is males and females of 15-45 years. The research is much interested in psychological challenges of counselors while counseling this age group, because of their vulnerability to high risk of sexual activity, sexually transmitted diseases and their reproductive age. This group of clients is the focus of the community as it is the productive age in different Government sectors which face stigma and discrimination or even rejection at work place. This group of clients normally visits the hospital for the treatment of sexually transmitted infections (STI), tuberculosis (TB) and HIV and AIDS counseling and testing because of partner/self's illness.

\subsection{Research Questions}

What are the psychological challenges faced by the counselor during counseling session?

Which are the models used by the counselor during counseling sessions?

What are the coping strategies used by the counselor during counseling session?

How effective are the coping strategies used by the counselor?

What are the possible solutions to counter the psychological challenges?

\section{What Is HIV and AIDS Counseling?}

Counseling is a facilitative process (Dyk, 2004) in which the counselor, working within the framework of a special helping relationship, uses specific skills to assist clients to develop self-knowledge, emotional acceptance, emotional growth and personal growth. Counseling is a process through which a person is helped to cope with some aspects of their life (A Training Manual for Training, 1992). This implies the helping of clients to see problems in perspective, to work out possible course of action, to make decisions and to implement them. Human Immuno-deficiency Virus (HIV) is a virus which attacks the blood cells of the body thereby reducing the body's ability to defend itself against different forms of infection. Acquired Immune Deficiency Syndrome (AIDS) is a collection of most common illness which affects people with HIV, (Training Manual, 2007). Jackson (1992) pointed out that, AIDS is a devastating epidemic that affects most countries in the world. Although it affects some countries more than others, everyone is affected by the pandemic. HIV and AIDS tends to hit people in their prime of their lives which is approximately between ages twenty-four and forty-five, typically representing a huge part of the work-force in any country (Hinds, 2008).

Professional counseling involves an interpersonal relationship between someone actively seeking help and someone willing to give help, who is capable of or trained to help in a setting that permits help to be given and received, (Training Manual, 2007). Bradley (1989) views HIV and AIDS counseling as a process where the health worker can help the patient to recognize the benefit and risk of HIV testing, or and get answers to their HIV related questions.

Counseling session is a joint process where the counselor provides information and psychological support (Makinde, 1984) so that the patient can make informed decision about HIV related issues. Counseling research indicates that by demonstrating empathy, warmth, concreteness, positive regard and genuineness, patients can be empowered to make life changes (Bradley, 1989). Although counselors cannot change the prognosis and cannot offer a cure, they can encourage realistic hope. Therefore, counseling helps a client to identify, clarify and resolve a problem in order to make an informed decision (Makinde, 1984). HIV counseling involves confidential dialogue between a client and a counselor aimed at enabling the person to evaluate personal risk of HIV transmission and make decisions related to HIV and AIDS. Therefore HIV and AIDS counseling is important in promoting behavior change.

\section{Methodology}

Manhumba rural district hospital (fictitious name) was conveniently sampled out (Wikipedia, 2012) in order to reduce expenses, time and for easy accessibility. Its population of 30 employees attracted researchers since it appeared an appropriate and good case study (Buskist \& Gerbing, 1990). Case studies provide understanding of social realities (Alasuutar, Bickman \& Brannen, 2008) as they are subjectively perceived, experienced and created by participants. Borg and Gall (1996) argues that, the case study approach is an in-depth study of instances of a phenomenon in its natural context and from the perspective of the participants involved in it. The 
case study examines one individual in depth through analysis of that individual's self-report. The case study was suitable for this research as it helped the researchers to discover psychological relationships and processes that applied to people in general.

Furthermore, the case study is particularly useful in clinical psychology, where therapies attempt to understand and modify individual's thinking or behavior. In this research, we found the psychological challenges faced by the counselor during HIV and AIDS counseling as the counselors would be helping the clients to face the reality of being HIV and AIDS positive. A case study is very useful as a source of hypothesis (Borg \& Gall, 1996) and the technique facilitates vigorous penetration of the unknown.

Case study in social science generally involves qualitative and quantitative methods. In this case the researcher used both qualitative and quantitative designs. Miles and Huberman (1998) credited the qualitative research methodology for its ability to provide data that is rich and contextual in detail. It is user friendly and acknowledges the role played by people as informants. The approach is humanistic in nature and gives room to inductive reasoning. On the other hand, quantitative research rests on the assumption that human behavior of matter can be objectively measured.

The population of counselors/health workers at Manhumba hospital is thirty, which is two trained counselors, four state registered general nurses and twenty-four primary care nurses and one registered general nurse who passed on in a car accident during the course of the research.

Findings may not easily be generalized to other cases or events. The above disadvantage of the research design was countered by using three research instruments which are the interview, questionnaire and focus group discussion. The issues which were not clearly understood by the counselor in the questionnaire were clarified during the interviews and focus group discussions. Issues which were sensitive or difficult to one counselor were clarified in the focus group discussion as counselors helped each other to answer some of the questions. So the research instruments complimented each other (Hogg \& Vaughan, 1995).

In this study, structured questionnaires, interviews and focused group discussions were used as data collection instruments. We had a group of four clients who had undergone HIV and AIDS counseling and a group of four health care workers.

To ensure validity and reliability of the research instruments, we used triangulation process (Borg \& Gall, 1996). Furthermore; a pilot study was conducted using two nurses who were involved in the counseling of HIV and AIDS. These two nurses were not involved in the study as they helped the researcher to rephrase some of the questions. The pilot study helped the researchers to source the information easily as ambiguous statements were corrected.

Sampling is done to reduce expenses, time and for easy accessibility. Wikipedia (2012) defined sampling as a process of selecting units, for example, people from a population of interest in this case counselors/health workers of Manhumba rural district hospital. We used the convenience sampling which is a non-probability sampling technique where subjects are selected due to their convenience, accessibility and proximity to the researchers (Wikipedia, 2012). The researcher preferred this sampling technique because it is fast, inexpensive, easy and the subjects were readily available. Five clients who underwent the HIV and AIDS counseling process were sampled into the focus group to bring out the psychological challenges faced by the counselors. Out of the thirty, there are only three male nurses. The researchers randomly sampled ten participants $(33.3 \%)$, eight females and two male nurses/counselors and five clients who were females who are living positively. Thirty-three point three percent (33.3\%) sample size was big enough to give reliable data with some external validity.

Ethics are issues that concern moral principles, value and issues of right and wrong. This research was conducted with certain ethical considerations in mind. First and foremost was the safe guarding the well-being of subjects regardless of whether they are animals or humans, (Buskist \& Gerbing, 1990). As researchers we had a special responsibility of treating our subjects with respect, dignity and concern for their physical and psychological safety. We gave the potential participants the opportunity to decline or withdraw from the research without fear of punishment. In general, we observed the ethical conduct principles which are protection from harm, right to privacy, informed consent, debriefing and confidentiality.

Appointments were done by the use of voice telephonic messages. We also presented an introductory letter to the responsible authority of the institution. The researcher handed over the questionnaires to the sister in charge of the hospital to ensure that the participants who are involved in counseling of HIV and AIDS at the hospital receive them. Data to consolidate the questionnaires was collected through the face to face interview and face to 
face focused group discussion before analysis.

\section{Results}

We found some in-depth information from the counselors on the issues concerning the psychological challenges they face during counseling sessions. Research questions were addressed, the psychological challenges faced by the counselors, models which are in use, coping strategies and solutions to counter the challenges were reported. The responses of focus group interviews from clients and counselors are given qualitatively.

Of the ten (10) participants, eight (8) were females, two (2) were males. Fifty percent (50\%) of the respondents were of the age group 26-35 years. Seven (7) respondents are married and have ordinary level as their educational qualification. Six (6) respondents are Primary Care Nurses with 2 weeks of HIV and AIDS training. All respondents (100\%) claim to be following Christian faith.

Table 1. Challenges faced by the counselor during HIV and AIDS counseling session. ( $\mathrm{N}=10)$

\begin{tabular}{lllll}
\hline & \multicolumn{2}{l}{ Respondents } & \\
Description & Male & Female & Total & Percentage \\
\hline Stress & 2 & 8 & 10 & 100 \\
Physical illness (headache) & 1 & 7 & 8 & 80 \\
Feeling helplessness & 0 & 4 & 4 & 40 \\
Feeling shame for the client & 1 & 5 & 6 & 60 \\
Feel the pain for the client & 0 & 7 & 7 & 70 \\
Have relatives with HIV and AIDS (affects counselors emotionally) & 1 & 7 & 8 & 80 \\
Lack of knowledge (due to no training) & 1 & 5 & 6 & 60 \\
Failure by clients (especially couples) to disclose (difficult clients) & 0 & 6 & 6 & 60 \\
Suppressed anger & 2 & 8 & 10 & 100 \\
Withdrawal & 1 & 6 & 7 & 70 \\
Burnout & 2 & 8 & 10 & 100 \\
Pressure of work & 2 & 8 & 10 & 100 \\
Time consuming & 2 & 4 & 6 & 60 \\
Feeling hungry & 0 & 3 & 3 & 30 \\
Taking home work related problems & 0 & 5 & 5 & 50 \\
Counselor's problems similar to the client (affected) & 0 & 2 & 2 & 20 \\
Exhausted & 1 & 5 & 6 & 60 \\
\hline
\end{tabular}

Table 1 shows the psychological challenges obtained from the questionnaires given to the respondents and face to face interview with the counselors. Stress, suppressed anger, burnout, pressure of work are the common psychological challenges faced by all the respondents.

Table 2. Models which can be used and those in use during HIV/AIDS counseling sessions. ( $\mathrm{N}=10)$

\begin{tabular}{|c|c|c|c|c|c|}
\hline \multirow{2}{*}{$\begin{array}{l}\text { Models which can } \\
\text { be used }\end{array}$} & \multirow{2}{*}{ Models used at the centre } & \multicolumn{2}{|c|}{ Number of Respondents using them } & \multirow{2}{*}{ Total } & \multirow{2}{*}{ Percentage } \\
\hline & & Male & Female & & \\
\hline Client centred & Client centred & 0 & 6 & 6 & 60 \\
\hline Family therapy & Family therapy & 0 & 1 & 1 & 10 \\
\hline Provider initiated & Provider initiated & 0 & 2 & 2 & 20 \\
\hline SPIKES & - & - & - & - & - \\
\hline $\mathrm{ABCDE}$ & - & - & - & - & - \\
\hline
\end{tabular}


The model mostly in use at the Hospital was the client-centred therapy. Counselors were not even aware of the SPIKES and ABCDE models. Four of the health workers were not even aware of any model but at times are expected to do the counseling when sent to clinics which are under hospital.

Table 3. Coping strategies used by counselors during HIV and AIDS counseling sessions. $(\mathrm{N}=10)$

\begin{tabular}{lllll}
\hline \multirow{2}{*}{ Coping strategies } & \multicolumn{2}{l}{ Respondents } & \multirow{2}{*}{ Total } & \multirow{2}{*}{ Percentage } \\
\hline Diversion & Male & Female & & \\
Breaking the session & 2 & 8 & 10 & 100 \\
Search for water & 1 & 7 & 8 & 80 \\
Leave the client to cry & 0 & 2 & 2 & 20 \\
Give tissues to wipe the tears & 2 & 8 & 10 & 100 \\
Encourage the client to cry & 2 & 8 & 10 & 100 \\
The counselor should not be carried away & 2 & 8 & 10 & 100 \\
Sharing with colleagues (someone) & 0 & 6 & 6 & 60 \\
Keep on smiling even when angry & 2 & 8 & 10 & 100 \\
Need to be strong & 0 & 2 & 2 & 20 \\
Refer to other counselors & 1 & 8 & 9 & 90 \\
Show the correct skill for clients to open up easily & 2 & 8 & 10 & 100 \\
Do not use words which offend the client & 0 & 3 & 3 & 30 \\
Use of support groups & 0 & 5 & 5 & 50 \\
Facilitate other counselors to help out & 2 & 8 & 10 & 100 \\
Prepare for the counseling session & 2 & 8 & 10 & 100 \\
\hline
\end{tabular}

Common coping strategies employed by the counselors during HIV and AIDS counseling are diversion, encouraging and leaving the client to cry, sharing with colleagues, referring to other counselors and use of support groups. However, counselors use a lot of other strategies which help clients to cope effectively with the challenges.

Table 4. Possible solutions to counter the psychological challenges. $(\mathrm{N}=10)$

\begin{tabular}{lllll}
\hline \multirow{2}{*}{ Description } & \multicolumn{2}{l}{ Respondents } & \multirow{2}{*}{ Total } & \multirow{2}{*}{ Percentage } \\
& Male & Female & & \\
\hline Sharing problems with expertise & 2 & 8 & 10 & 100 \\
Sharing problems with colleagues & 2 & 8 & 10 & 100 \\
Refresher courses & 2 & 8 & 10 & 100 \\
Changing the environment & 0 & 5 & 5 & 50 \\
Training health workers to be counselors & 2 & 8 & 10 & 100 \\
Further training for counselors & 1 & 6 & 7 & 70 \\
Frequent counseling of counselors & 2 & 8 & 10 & 100 \\
More workshops & 2 & 8 & 10 & 100 \\
Support from superiors and colleagues & 2 & 8 & 10 & 100 \\
Leave the session when stressed & 2 & 8 & 10 & 100 \\
Employ more counselors & 2 & 8 & 10 & 100 \\
Pay counselors better salaries & 2 & 8 & 10 & 100 \\
\hline
\end{tabular}


The possible solutions to counter the psychological challenges are presented in the table above. Most of the solutions were cited by almost all the counselors except two that is the changing of the environment and further training for the counselors. This implies that most of the solutions were recommended by almost all the counselors.

\subsection{Responses from Face to Face Focus Group of Counselors and Clients}

The responses from the focus group discussions complimented information from the face to face interview and questionnaire.

Do clients (you) normally come for voluntary counseling? Why?

Table 5. Responses from the counselors

\begin{tabular}{llll}
\hline Description & Questionnaire & Focus Group Interview & Face to Face Interview \\
\hline Voluntary & $50 \%$ & $40 \%$ & $50 \%$ \\
Referred & $50 \%$ & $60 \%$ & $50 \%$ \\
\hline
\end{tabular}

The Table indicates that most of the clients who came for HIV and AIDS counseling and testing are the referred group, which is according to the focus group interview. The questionnaire and the face to face interview revealed that $50 \%$ are referred and $50 \%$ are voluntary.

The clients interviewed revealed that they went for HIV and AIDS counseling not because they wanted to, but because of the illness of their children. The clients indicated that, because of the children's illness, health workers advised them to go for counseling. This is an indication that some clients went for counseling because they were referred and not because they wanted to.

Do clients (you) open up easily during the counseling session? Why?

The counselors revealed that, there were other clients who open up easily and some who are difficult to deal with. The counselors went on to say that, clients open up easily provided the counselor follows the proper procedures and show the appropriate skills. "However, nowadays clients open up easily except a few", said one counselor.

The clients indicated that at first, it was difficult for them to open up during the session. When the results showed that they were HIV and AIDS positive, they denied the results for almost one month. The clients did not open up easily because of the fear of stigma, isolation and being called names, for example, 'a prostitute' and being discriminated against.

Are clients (you) assured of privacy and confidentiality during counseling sessions?

The counselors indicated that the clients are assured of privacy and confidentiality but however, there are some disturbances which might take place, for example, a visitor needing the counselor's attention, somebody knocking on the door and some other staff needing immediate help. The infrastructure is not adequate for the session to maintain the privacy. While the clients revealed that they are assured of privacy and confidentiality but when waiting to enter the room, clients would be seated outside where everybody sees that this person is waiting for a counseling session. At times when in the session, somebody might knock and open the door unexpectedly. The clients revealed that they will feel uncomfortable to open up easily.

Do you (counselors) at times cry during the session?

The counselors revealed that they may want to cry but they will restrain themselves on professional grounds. In local language they said (ungada kuchema asi hauzochemi, zvekare, murwere anogona kuita problem seyako, zvakaoma shamwari asi hauzviratidzi) and at times the client might have the same problem as the counselor's but the counselor must not show any form of emotion to the client. The counselors also indicated that at times they might be angered by the clients but should maintain their professionalism. The client revealed that the counselors did not show that they are "touched" by the client's stories, they did not cry or showed any sign of anger during the session.

Are clients (you) given enough time to say what they (you) want?

The counselors revealed that clients are given enough time to say what they want during the counseling session. During interviews, counselors indicated that clients are given thirty minutes and above and the session can go up to one hour. Counselors indicated that at times they counsel about fifteen (15) to twenty (20) clients per day. 
These figures indicated more pressure of work to the counselor.

The clients indicated that at first they were given about forty-five minutes during the session. The clients revealed that nowadays the counselors give them less time as the counselors want to serve other clients (Itai chop chop tibatsire vamwe). This is an indication of pressure of work.

\section{Discussion}

There were ten health workers/ counselors who participated in the research. Eight of the participants were female and two were male. Two males participated as there were only three males working at the hospital. The participants (100\%) claimed to be of the Christian faith and (60\%) were primary care nurses, two counselors and two registered general nurses.

\subsection{Psychological Challenges Faced by the Counselor during HIV and Aids Counseling}

Table 1 indicated the psychological challenges faced by the counselors during HIV and AIDS counseling. These were sourced through the use of questionnaire, face to face interview with the clients and counselors. The most common psychological challenges with (100\%) are stress, suppressed anger, burnout and pressure of work out of the seventeen psychological challenges. The psychological challenges have been brought about because HIV and AIDS is a life threatening illness and issues involved in it may be painful, frightening and threatening to both the counselor and the client (Hinds, 2005). Emotions are affected, both of the counselor and the client.

All the ten counselors revealed that they were stressed by the counseling session because of attending to young children with HIV and AIDS, stress of work and working for more than eight (8) hours. The counselors also indicated that they have relatives who are HIV and AIDS positive. Jackson (1992) purports that HIV and AIDS work are stressful because it means repeatedly facing ill health suffering and death of people of different ages. Furthermore, the counselors might have problems which are similar to the client as indicated by two of the counselors i.e. they are affected. Counselors indicated that at times they got angry with the behavior shown by clients who are difficult to deal with but they are expected to act professionally. This concurred with what was said by Chiremba (2004) who postulates that, health practitioners are usually the soft target for the client's anger associated with the bad news but counselors are expected to act professionally and not fight back.

Twenty percent of the counselors indicated one of their challenges is lack of knowledge as one of them indicated that 'counseling yacho tinoita pachinurse' meaning counseling is done from the nursing perspective and not as counselors. This concurs with earlier research done (Jones, 2000) which indicated that some health workers have trouble in breaking bad news to the client due to little or no opportunities to gain the skills needed to do counseling in a sensitive and professional manner.

During the group discussion interview with the clients, one of them revealed that it took her time to accept the positive results (machine wenyu wakafa nurse). Rauh (1995) highlighted that many people deny the information on HIV and AIDS infection given by the health worker and provide all sorts of rationale and reasons to the results.

Burnout was revealed as one of the psychological challenges by the counselors. People providing HIV and AIDS related services, are particularly predisposed to psychological stress and burnout (Training Manual, 2007). Further, counselors provide support to patients that have an incurable disease that is associated with taboos. In some Shona cultures people tend to connote HIV and AIDS disease to be a disease of the towns (UNICEF, 1992).

Seventy percent $(70 \%)$ of the counselors indicated that they felt the pain for the client (unonzwa kurwadziwa kunyanya kucounselor vana). The pain is caused by life threatening illness (AIDS) and issues associated with the disease. During the group interview with the clients one of them revealed that she was still in pain even if she had undergone the counseling process. The fact that she was HIV positive was haunting her (Murume wangu wakandirwadzisa, kundivigira chirwere kubva kuSouth i.e. to say my husband pained me because he contracted the disease in South Africa where he was working and brought the disease here). She ended up weeping for some time. Other clients were courageous to talk but we observed that the clients had difficulties while talking. Clients may feel angry (Jackson, 1992). With themselves or with whomever would have transmitted the virus to them.

Confronting the realities of HIV and AIDS may generate a variety of fears that may cause emotional strain. The emotions shown by the clients during the group interview indicated that counselors had problems dealing with clients, which could lead to psychological challenges during HIV and AIDS counseling session.

\subsection{Models Which Can Be Used and Those in Use during the HIV and Aids Counseling}

Table 2 indicated the models which were used by the counselors during counseling session. The mostly used 
model at the hospital was the client centred approach as sixty percent of the counselors revealed that they mostly rely on client-centred approach. The responses of counselors concurred with the literature from the Trainee Manual (2007) which revealed that Voluntary Counseling and Testing is the mostly common available model for testing for HIV in both clinical and non-clinical settings. However, the questionnaire and face to face interview revealed that $50 \%$ of the clients were referred cases and $60 \%$ from the focus group interview were referred. Clients indicated that they went for counseling not because they wanted to, but because of the illness of their children. This is an indication that clients were driven by the situation in which they found themselves in. It may also be an indication why counselors find difficult cases during the counseling sessions as clients were not the ones who initiated the counseling. Kaleeba (1992) reveals that the persuasion process is tiresome, as the counselor is not supposed to ridicule or argue with the client. Therefore, highly skilled counselors are needed to deal with such cases.

The counselors indicated that they were not aware of the SPIKES and the ABCDE model; however, they were aware of some techniques of these models like the setting up and communication skills. Some of these skills, according to one counselor were just theoretical and not in use. Forty percent of the counselors were not even aware of any model including VCT, they did counseling blindly. Chiremba (2004) pointed that it is in the domain of communication where most health practitioners are found wanting.

\subsection{Coping Strategies}

Counselors revealed sixteen coping strategies which are indicated in Table 3. The most common strategies employed by the counselors were: encouraging the client to cry, sharing with colleagues, referring to other counselors and use of support group. Eighty percent of the counselors revealed that when dealing with difficult cases, at times, it is wise to break the session as the counselor might get angry. Rauh (1995) said that counselors must take break from the caring role and feel justified in seeking personal support as needed.

The counselors indicated that they had difficult cases, one of the cases involved a man who had signs and symptoms of HIV and AIDS. The man refused to be tested and was emotional (Handidi kutestwa, ndirapei chete-meaning to say that I don't want to be tested, just treat me). Faber and Reinhart (1982) pointed out that argument about being tested may occur as the client might decide against being tested as the knowledge of being tested HIV positive might affect the client for life. On the other hand, the counselors and nurses were angered by the man. However, Makinde (1982) pointed out that, counselors are expected to cope professionally with their emotion, hide the emotions, however, upset, angry or frustrated.

The counselors also revealed that, at times they share the experiences with colleagues so that it would be easier when faced with that challenge later. The responses concurred with Jackson (1992) who purports that counselors are encouraged to find others who have been through or are going through the same situation and share experiences, that is learning from each other.

Twenty percent of the counselors indicated that they were always smiling during the session even if the client offended them. This coping strategy was effective for the counselors as the client ended up disclosing information which they did not want to. Trainee Manual (2007) posits that, listening to the clients attentively, encouraging them to talk by nodding, smiling and simple probing helps clients to open up easily. Counselors indicated that if they showed the correct skill for clients like empathy, trustworthy, honest, and privacy, clients will open up easily. Empathy offers support (Dyk, 2004), built trust, pave way for more effective participation from the client and create an atmosphere for stronger interventions by the counselor.

Counselors revealed that clients are needed to be given enough time for them to cry. This helped to reduce tension within the client. At times the client would keep on crying to the extent of breaking the session as there would be other clients who also needed to be counseled. However, crying is necessary in order to vent out all the emotions (Kaleeba, 1992).

Thirty percent $(30 \%)$ of the counselors placed emphasis on preparation of the counseling session. One counselor mentioned that setting up of the room is crucial for the client to open up. The environment need to be conducive as the counselor is expected to welcome the client and made sure the room is private and confidential. However, there were at times knocks at the door which affected the client.

Furthermore, the hospital does not have enough infrastructures as a result clients would be seen by everyone queuing outside waiting for their turn. This made the clients uncomfortable and made them think twice before entering the counseling room. This affected the preparations that would have been done by the counselors thereby reducing the effectiveness of the strategies employed by the counselor. 


\subsection{Possible Solutions}

Workers who may be affected, (HIV positive) are involved with counseling the infected, the ill and the dying people. Such workers highly need psychological support in order to cope emotionally. Teamwork among counselors is expected as they share experiences, clients and overall workload (Jackson, 1992).

Counselors indicated that they needed to share their problems with other experts. They also need a counselor. They need somebody to "empty out" their innermost being. During workshops counselors can share experiences (Kaleeba, 1992) and how to cope with particular problems. Kaleeba further contend that a private consultant can be called in for regular counseling of counselors.

The hospital has only two trained counselors and the rest are nurses who just attended HIV and AIDS workshops for either a week or two. The work load is too much for the counselors and nurses as they are expected to work with a total of more than 32000 patients. All the health workers revealed that they needed further training to deal with the counseling effectively and also to be more competent. Training programmes on HIV and AIDS counseling can be organized to improve skills for health staff (Rauh, 1995) so as to feel more competent. Trainee Manual (2007) added that counselors can update or increase their HIV and AIDS knowledge and counseling skills as most counselors and health workers in Zimbabwe that provide HIV and AIDS counseling had few hours to weeks of training.

\section{Conclusion}

The research results indicated that the counselors at the hospital face psychological challenges during HIV and AIDS counseling session. It is concluded that the Ministry of Health and Child Welfare should organize workshops for healthcare staff or counselors so as to share experiences, discuss problems and share feelings and discuss issues pertaining to successful HIV counseling. There is also need for Counselors to be further trained to keep abreast with modern trends in HIV counseling. Training programmes on HIV and AIDS counseling can be organized to increase counseling skill, for health staff to feel more competent. A consultant may be called onto the site for regular counseling of counselors. Workloads for employees can be interspersed with less stressful aspects of the job. The Ministry should employ more counselors or heath staff to reduce pressure of work and above all motivation of employees is always very critical (Mwamwenda, 1996) if organizational objectives are to be achieved and this hospital is no exception.

\section{Acknowledgements}

This paper was a result of contributions made by the Superintended and staff of hospital and in this regard we would like to acknowledge the role they played individually and collectively in making this research a success.

\section{References}

Aluusutar, P., Bickman, L., \& Brannen, J. (Eds.). (2008). The Sage Handbook of Social Research Methods. London: Sage Publications.

Bork, W. R., \& Gall, M. D. (1983). Educational Research: An African Introduction. New York: Longman.

Borg, W. R., \& Gall, M. D. (1996). Educational Research: An Introduction. New York: Longman.

Buskist, W., \& Gerbing, W. D. (1990). Psychology. Haper Collins Publishers, USA.

Chiremba, W. (2004). Health Behavior. Harare: ZOU.

Dyle, A. V. (2004). HIV/AIDS Care and counseling (3rd ed.). Capetown: Pearson Education.

Eberhardt, T. L. (1996). Breaking Bad News. London: Chapman and Hall.

Faber, M. M., \& Reinhardt, S. (1982). Promoting Health through Risk Reduction. New York: Macmillan Publishers.

Groomely, A. N. (1986). Understanding Psychology. New York: Random House.

Gudyanga, A., \& Gudyanga, E. (2012). Selection of science subjects at advanced level by females: aetiology and challenges. The Dyke, 6(2), 114-130.

Hinds, J. M. (2008). Fighting the AIDS and HIV epidemic: A global battle. Enslow: Publishers, USA.

Hogg, A. M., \& Vaughan, G. M. (1995). Social Psychology; An Introduction. Prentice Hall, Australia.

Holdsworth, W. (1982). Psychology for Career Counseling. Macmillan Press Ltd, USA.

Jackson, H. (1992). AIDS Action now. Harare: AIDS Counseling Trust.

Jones, N. R. (2000). Practical Counseling and Helping skills. London: Sage Publications. 
Kaleeba, N. (1991). We miss you all. Kampala: UNICEF.

Kaleeba, N. (1992). AIDS in the family. Harare: UNICEF.

Makinde, O. (1984). Fundamentals of Guidance and Counseling. Nairobi: Macmillan Publishers.

Matlin, M. W. (1992). Psychology. Tokyo: Harcout Brace Jevanovich College Publishers.

Mottiar, S. (2012). Socio-economic rights and development: HIV/AIDS and antiretroviral service delivery in South Africa. African Responses to HIV/AIDS, Between Speech and Action. University of KwaZulu Natal. KwaZulu Natal.

Moyo, S., \& Chiware, B. R. (1995). Educational Administration and Management. Harare: Mazongororo Printers.

Mwamwenda, T. S. (1996). Educational Psychology: An African Perspective. Heinemann, Butterworth Publishers.

Nkwi, P. N., \& Bernard, H. R. (2012). Culture, behaviour and AIDS in Africa. African Responses to HIV/AIDS, Between Speech and Action. University of KwaZulu Natal. KwaZulu Natal.

Rauh, E. (1995). AIDS Reading on a Global Crisis: Peer Educators. London: Allyn and Bacon.

Sahu, B. K. (2004). AIDS and Population Education. New Delhi: Sterling Publishers Pvt Ltd.

Training Manual for Trainers. (1992). National HIV Testing and Counseling. Harare: Ministry of Health.

Training Manual. (2007). National HIV Testing and Counseling. Harare: Ministry of Health.

\section{Copyrights}

Copyright for this article is retained by the author(s), with first publication rights granted to the journal.

This is an open-access article distributed under the terms and conditions of the Creative Commons Attribution license (http://creativecommons.org/licenses/by/3.0/). 